\title{
DETECTION OF SALMONELLA SP. FROM PORCINE ORIGIN: A COMPARISON BETWEEN A PCR METHOD AND STANDARD MICROBIOLOGICAL TECHNIQUES
}

\author{
Sandra Maria Ferraz Castagna ${ }^{1}$; Monika Muller²; Marisa Macagnan²; Carla Rosane Rodenbusch²; \\ Cláudio Wageck Canal²; Marisa Cardoso ${ }^{2 *}$ \\ ${ }^{1}$ Universidade do Estado de Santa Catarina, Florianópolis, SC, Brasil; ${ }^{2}$ Universidade Federal do Rio Grande do Sul, \\ Porto Alegre, RS, Brasil
}

Submitted: March 21, 2005; Returned to authors for corrections: August 10, 2005; Approved: October 21, 2005

\begin{abstract}
The aim of this study was to compare a polymerase chain reaction (PCR) method combined with selective enrichment in Rappaport-Vassiliadis broth (PCR-RVB) with standard microbiological techniques (SMT) for the generic detection of Salmonella in samples of porcine origin. Two hundred sixty eight field samples consisting of 42 sets of pooled porcine mandibular lymph nodes and tonsils, 44 samples of intestinal content, 38 pork sausage meat samples and 144 samples of feed collected from swine farms were submitted to the PCR-RVB and SMT protocols. Salmonella was detected in 54 samples using the PCR-RVB assay and in 42 samples by SMT, three of the SMT Salmonella-positive samples (one each of $S$. Derby, $S$. Panama and $S$. Typhimurium) being Salmonella-negative by PCR-RVB. For the PCR-RVB method 15 Salmonella-positive samples were negative by SMT, a significant difference according to the Mac Nemar's chi-squared test ( $\mathrm{p}=0.0153$ ). Subsequent serological typing of the SMT isolates showed the following Salmonella serovars, the number of positive samples being given in parentheses: Typhimurium (12); Bredeney (10); Panama (5); Saint-paul (5); Minnesota (3); Mbandaka (2); Derby (1); Enteritidis (1); Orion (1) and Salmonella sp. (2). We concluded that, although the use of both PCR-RVB and SMT increased the number of positive samples, the PCR-RVB, due to its higher sensitivity and greater speed in giving results, can be implemented to detect Salmonella in samples of porcine origin.
\end{abstract}

Key words: detection, PCR, pork, Salmonella, swine

\section{INTRODUCTION}

Salmonella is one of the most important pathogens involved in human foodborne illness. The majority of human salmonellosis cases are caused by the consumption of contaminated egg, poultry, pork, beef and milk products $(6,10)$.

Salmonella control programs at the pre- and post harvest level require reliable, rapid and internationally accepted diagnostic methods. Currently, routine Salmonella diagnostic procedures are still based on conventional bacterial culturing, resulting in up to seven days isolation procedures (8).

The polymerase chain reaction (PCR) represents a major advance in terms of the speed, sensitivity and specificity of diagnostic methods and has been increasingly used to identify several bacterial species in food and clinical samples $(4,19)$. Another advantage is that PCR is not dependent on utilization of a substrate or the expression of antigens, thereby circumventing the phenotypic variations in biochemical patterns and lack of detectable antigens (13). Both non-selective and selective enrichment have been combined with PCR for the detection of various bacterial pathogens $(4,11,16,18)$, enrichment not only improving sensitivity but also serving to dilute substances that can inhibit the PCR (7).

In southern Brazil, standard microbiological techniques (SMT) have recently been used to isolate Salmonella from pigs at slaughter and pork products $(3,5)$, pointing the need of starting monitoring and control programs in this region.

*Corresponding Author. Mailing address: Faculdade de Veterinária, UFRGS, Av. Bento Gonçalves 9090, Porto Alegre, RS, Brasil. 91540-000. Tel.: (+5551) 3316-6123; Fax: (+5551) 3316-7305; E-mail address mcardoso@ufrgs.br 
The aim of the work presented in this paper was to compare standard microbiological techniques (SMT) for the detection of the genus Salmonella with a combined PCR and selective enrichment in Rappaport-Vassiliadis broth method (PCR-RVB) using pig-related field samples.

\section{MATERIALS AND METHODS}

\section{Field samples}

One hundred and twenty four pig-derived field samples were collected in a southern Brazilian abattoir and meat-processing plant with a high prevalence of Salmonella (5). The samples consisted of 42-pooled sets of mandibular lymph nodes and tonsils (LT), 44 intestinal content (IC) samples and 38 samples of pork sausage meat (PSM). Furthermore, 144 feed (F) samples collected in three swine farms were included in the study.

\section{Artificially contaminated samples}

Six Salmonella-negative feed aliquots ( $25 \mathrm{~g}$ ) were artificially contaminated with each 2 colony forming units (cfu/g), $20 \mathrm{cfu}$, or $200 \mathrm{cfu} / \mathrm{g}$ of Salmonella Typhimurium and submitted to both standard microbiological and polymerase chain reaction protocols.

\section{Standard microbiological techniques (SMT)}

For pre-enrichment, $25 \mathrm{~g}$ of sample was inoculated into 250 $\mathrm{mL}$ of $1 \%$ buffered peptone water (BPW) and incubated at $37^{\circ} \mathrm{C}$ for $18-24 \mathrm{~h}$. For enrichment, $1 \mathrm{~mL}$ of BPW culture was transferred to $9 \mathrm{~mL}$ of Salmonella-selective Müller-Kauffmann tetrathionate (MK-TB; Merck) broth and incubated at $42^{\circ} \mathrm{C}$ and a further 0.1 $\mathrm{mL}$ added to $9.9 \mathrm{~mL}$ of Salmonella-selective RappaportVassiliadis (RVB; Merck) and incubated at $37^{\circ} \mathrm{C}$ for $24 \mathrm{~h}$. After incubation, $1 \mathrm{~mL}$ of RVB was set aside for DNA extraction and PCR analysis and a loop from each of the broths was streaked, separately, onto a plate of Xylose lysine tergitol 4 agar (XLT4) and a plate of Brilliant green agar plus $4 \%(\mathrm{w} / \mathrm{v})$ novobiocin, both of which were incubated at $37^{\circ} \mathrm{C}$ for $24 \mathrm{~h}$. Presumptive Salmonella colonies were characterized by biochemical assays (12), and somatic and flagellar antigen determination using slide agglutination and were also serotyped at a reference center (Fundação Osvaldo Cruz, Rio de Janeiro, Brazil). These procedures were repeated for each sample. Pure cultures of $S$. Typhimurium and $S$. Enteritidis were used as positive controls and Proteus vulgaris as a negative control, these strains being inoculated into RVB and MK-TB and treated in the same way as the samples.

\section{DNA extraction}

For DNA extraction, $1 \mathrm{~mL}$ of a $18 \mathrm{~h}$ old RVB culture (described above) was centrifuged at $2000 \mathrm{~g}$ for $4 \mathrm{~min}$ and the pellet resuspended in $444 \mu \mathrm{L}$ of Tris-EDTA buffer $\left(10 \mathrm{mmol} \mathrm{l}^{-1}\right.$ Tris- $\mathrm{HCl}(\mathrm{pH} 8.0)$ and $1 \mathrm{mmol}^{-1}$ EDTA) containing $30 \mu \mathrm{L}$ of
$50 \mathrm{mg} \mathrm{mL}^{-1}$ lysozyme (Pharmacia Biotech) and incubated at $4^{\circ} \mathrm{C}$ for $30 \mathrm{~min}$, after which $25 \mu \mathrm{L}$ of $10 \%$ (w/v) SDS and $1.25 \mu \mathrm{L}$ of proteinase $\mathrm{K}\left(20 \mathrm{mg} \mathrm{mL}^{-1}\right.$, GibcoBRL) were added and the solution incubated at $55^{\circ} \mathrm{C}$ for $30 \mathrm{~min}$. A $500 \mu \mathrm{L}$ volume of phenol-chloroform (1:1), $\mathrm{pH} 8.0$, was added and mixed for 5-10 s before centrifuging at $16000 \mathrm{~g}$ for $4 \mathrm{~min}$, after which the liquid phase was once more extracted with phenol-chloroform and then with chloroform only. The DNA was precipitated with sodium acetate and cooled isopropanol and incubated at $-20^{\circ} \mathrm{C}$ for $30 \mathrm{~min}$, centrifuged at $16000 \mathrm{~g}$ for $10 \mathrm{~min}$ at $4^{\circ} \mathrm{C}$, following which the supernatant was removed and the DNA pellet washed with $1 \mathrm{~mL}$ of $80 \%$ cooled ethanol and then resuspended in $50 \mu \mathrm{L}$ of Tris-EDTA buffer and used immediately or stored at $20^{\circ} \mathrm{C}$. This procedure was repeated for each of the samples and the positive and negative controls.

\section{Polymerase chain reaction DNA amplification}

The oligonucleotide primer set used was 139 (5'GTGAAATTATCGCCACGTTCGGGCAA3') and 141 (5'TCATCGCACCGTCAAAG GAACC3'), amplifying a 284 bp fragment from the Sallmonella invA gene $(9,17)$, this fragment being common to all members of the genus Salmonella but absent from other genera. Polymerase chain reactions were performed using $2 \mu \mathrm{L}$ of the extracted DNA, $2.5 \mathrm{mmol}^{-1} \mathrm{MgCl}_{2}$, $10 \mathrm{mmoll}^{-1}$ Tris $\mathrm{HCl}(\mathrm{pH} 8.0), 5 \mathrm{mmoll}^{-1} \mathrm{KCl}, 0.2 \mathrm{mmoll}^{-1}$ of each nucleotide (GibcoBRL), $0.8 \rho \mathrm{mol} \mu \mathrm{L}^{-1}$ of each primer and $1 \mathrm{U}$ of Taq DNA Polymerase (Cenbiot Enzimas, Porto Alegre, Brazil) in a final volume of $25 \mu \mathrm{L}$. Amplifications were carried out in a GeneAmp PCR System 2400 thermocycler (Perkin Elmer Instruments) using the conditions determined by Oliveira $e t$ al., 2002 (15) according to the following protocol: initial denaturation at $94^{\circ} \mathrm{C}$ for $5 \mathrm{~min}$, followed by 35 cycles of denaturation at $94^{\circ} \mathrm{C}$ for $1 \mathrm{~s}$, primer annealing at $55^{\circ} \mathrm{C}$ for $1 \mathrm{~s}$ and extension at $72^{\circ} \mathrm{C}$ for $21 \mathrm{~s}$; with a final extension at $72^{\circ} \mathrm{C}$ for 7 min. Amplification products were separated by electrophoresis on $1.2 \%(\mathrm{w} / \mathrm{v})$ agarose gels containing $5 \mu \mathrm{g} \mathrm{mL} \mathrm{m}^{-1}$ of ethidium bromide, a 100 bp DNA ladder (GibcoBRL) being used as a molecular weight marker.

\section{Statistical analysis}

MacNemar Test was performed on the data using GraphpadInstat (1993). Sensitivity and predictive value rates were calculated as previously described (20).

\section{RESULTS}

\section{Detection of Salmonella in field samples}

Fifty-seven samples were Salmonella positive and 211 negative using PCR-RVB and SMT. The PCR-RVB method and SMT both detected 39 (31.45\%) positives from the 268 field samples. Serological typing detected the following Salmonella serovars in the 42 SMT Salmonella-positive samples, the 
number of samples positive for that serovar being shown in parentheses: Typhimurium (12); Bredeney (10); Panama (5); Saint-paul (5); Minnesota (3); Mbandaka (2); unidentified Salmonella serovar (2); Derby (1); Enteritidis (1); and Orion (1) (Table 1). S. Derby, $S$. Panama and $S$. Typhimurium were detected in three SMT-positive samples that were negative by PCR-RVB.

Of the 268 samples tested, SMT resulted in 42 (12 LT, 6 IC, 24 PSM) Salmonella-positive samples, only three of which were negative by the PCR-RVB, while the PCR-RVB method gave 54 (17 LT, 10 IC, 25 PSM, 2 F) Salmonella-positive samples (Fig. 1), 15 of which were negative by SMT (Table 2).

A sample was considered Salmonella-positive when either the SMT or PCR-RVB gave a positive result, based on which the sensitivity of the SMT was $73.6 \%$ while that of the PCRRVB method was $94.7 \%$. The negative predictive value (i.e. the confidence in a negative reaction actually representing the absence of Salmonella) was $98.6 \%$ for the PCR-RVB method and $93.3 \%$ for SMT. The kappa comparability value between the two sampling methods was 0.77 .

Salmonella was detected by PCR-RVB in all eighteen feed aliquots artificially inoculated with different concentrations of $S$. Typhimurium. On the other hand, SMT failed to detect Salmonella in one aliquot inoculated with $2 \mathrm{cfu} / \mathrm{g}$ of $S$. Typhimurium.

\section{DISCUSSION}

Since pork products are a significant source of human infection, the emphasis in the present study was to test a PCR protocol for the detection of the genus Salmonella from pigs and pork products and to compare the new method with standard microbiological techniques (SMT).

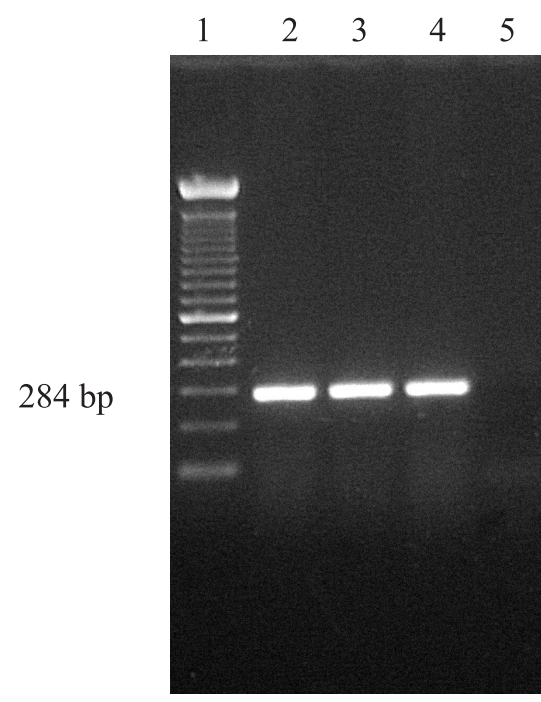

Figure 1. Electrophoresis of PCR products on $1.2 \%$ agarose gel stained with ethidium bromide: $100 \mathrm{bp}$ molecular weight marker (lane 1); positive control (lane 2); positive samples (lanes 3 and 4); negative control (lane 5).

Table 2. Number of Salmonella-positive and Salmonellanegative field samples by standard microbiological techniques (SMT) and polymerase chain reaction (PCR-RVB).

\begin{tabular}{lccc}
\hline & $\begin{array}{c}\text { SMT } \\
\text { positive }\end{array}$ & $\begin{array}{c}\text { SMT } \\
\text { negative }\end{array}$ & Total \\
\hline PCR-RVB positive & 39 & 15 & 54 \\
PCR-RVB negative & 3 & 211 & 214 \\
\hline Total & 42 & 226 & 268 \\
\hline
\end{tabular}

Table 1. Number and percentage $(\%)$ of samples positive by standard microbiological techniques (SMT) and polymerase chain reaction (PCR-RVB).

\begin{tabular}{|c|c|c|c|}
\hline \multirow[t]{2}{*}{ Samples (number) } & \multicolumn{2}{|c|}{ Positive samples (\%) } & \multirow[t]{2}{*}{ Number of samples positive by SMT for that serovar } \\
\hline & SMT & PCR-RVB & \\
\hline Pork sausage meat (38) & $24(63)$ & $25(66)$ & $\begin{array}{l}\text { Bredeney (8)*, Typhimurium (3), Saint-paul (5), Panama (3), } \\
\text { Enteritidis (1), Mbandaka (1), Minnesota (2), unidentified } \\
\text { Salmonella serovar (1) }\end{array}$ \\
\hline $\begin{array}{l}\text { Pooled mandibular lymph } \\
\text { nodes and tonsils (42) }\end{array}$ & $12(28)$ & $17(40)$ & Typhimurium (7), Bredeney (2), Derby (1), Orion (1), Panama (1) \\
\hline Intestinal content (44) & $6(14)$ & $10(23)$ & $\begin{array}{l}\text { Typhimurium (2), Mbandaka (1), Minnesota (1), } \\
\text { Panama (1), unidentified Salmonella serovar (1) }\end{array}$ \\
\hline Total (124) & $42(34)$ & $52(42)$ & \\
\hline
\end{tabular}

*The number of positive samples of the given serovar is shown in parenthesis. 
The PCR-RVB method for the detection of Salmonella at genus level was tested in parallel with SMT using 268 field samples, resulting in about $21 \%$ more samples being Salmonellapositive by the PCR-RVB method than by SMT. The MacNemar test showed that there was a significant difference $(p=0.0153)$ between the total number of SMT positive samples and the total number of PCR-RVB positive samples. These results agree with a previous study (15) in which the same PCR-RVB protocol was compared with SMT using poultry-related samples, although in the formerly case the PCR-RVB assay detected about $128 \%$ more positive samples than SMT, possibly due to the different nature and the amount of samples analyzed.

The PCR-RVB assay had the advantage that it could be performed in up to five days less than SMT, but the use of both methods could increase the number of positive samples. It has been pointing that $\mathrm{PCR}$ with selective enrichment detected more positive samples than the SMT, because the selective enrichment dilutes PCR inhibitory substances and inhibits competitive microflora, which allows the target microorganism to grow thus increasing the quantity of target DNA (18).

Bacteria, which are naturally present in food and feed samples, usually have reduced viability due to prolonged exposure to unfavorable conditions such as high salt concentration, unsuitable $\mathrm{pH}$ values, freezing, and heating. The combination of pre-enrichment and PCR offers the advantage of enhancing the sensitivity of the PCR method by increasing the number of microorganisms from $10^{6}$ to $10^{9} \mathrm{cfu} / \mathrm{mL}$ during the pre-enrichment step, while reducing the negative influence of the complex food matrix by dilution of the sample (13). Using this methodology, there will be no increase in the DNA of nonviable cells during the pre-enrichment step and the risk of false-positives should be reduced.

All of the 39 samples that were Salmonella-positive by SMT were also Salmonella-positive by the PCR-RVB method, which also detected 15 additional Salmonella-positive samples. We propose that the additional 15 Salmonella-positive samples were detected because the PCR assay was more sensitive than the SMT method. Studies formerly conducted $(14,15,17)$ concluded that the primer set $139-141$ is highly specific and that the predicted amplicon is only generated by Salmonella strains. By testing non-Salmonella genus, commonly present in samples analyzed by PCR, only few strains that resulted in non-specific amplification of faint non-target-sized fragments were detected $(14,17)$. Thus, the amplification of the gene inv $\mathrm{A}$ has been proposed as an international standard for Salmonella detection (14).

The failure to detect some Salmonella positive samples by SMT was possible related to the fact that isolates in these samples produced colonies lacking the characteristics of Salmonella colonies leading to false-negative results (2). It could be also related to the amount of Salmonella present on the sample. In the present study, when a low number $(2 \mathrm{cfu} / \mathrm{g})$ of Salmonella was inoculated in feed aliquots $(n=6)$, SMT was not able to detect one of the positive samples, while PCR-RVB assays were positive for all experimentally inoculated feed aliquots.

The DNA of three Salmonella isolates (one of each serovar Derby, Panama and Typhimurium) was not detected by the PCRRVB method, these strains being isolated by SMT and identified biochemically and by serotyping. Even considering that three strains were not detected by the PCR-RVB method, the negative predictive value of the PCR-RVB method tested was higher than that from SMT, conferring more confidence on negative results as compared to those produced by SMT. Moreover, the kappa value indicated that there was a good comparability between both tests (1). In two occasions (isolates of serovar Derby and Panama) the strain was isolated only from MK-TB. This may be due to a higher sensitivity of these strains to the selective agents in RVB, impairing their grow in RVB and resulting in the absence of the target DNA for the PCR detection. On the other hand, the Typhimurium strain was isolated from the RV broth by the SMT, so we can conclude that the target DNA was present in the broth tube. Previous studies $(14,17)$ also reported a few Salmonella isolates, which were not detected using the same primer set (139-141). In spite of some speculations that the gene invA could be absent in some rare Salmonella strains (9), the failure to detect this $S$. Typhimurium strain was probably more related to the presence of PCR inhibitors in the sample. More recently, the co-amplification of an internal amplification control to indicate possible inhibitory substances derived from the sample was proposed (14). The inclusion of an internal control may contribute to achieve a higher confidence on Salmonella negative PCR-RVB results in pork.

The increasing importance of pigs and pork as a major source of $S$. Typhimurium isolation in many countries including Brazil $(3,5)$, emphasize the need of accurate diagnostic tools. In this connection, the PCR-RVB methodology described here was able to decrease the time needed to detect Salmonella and has potential for rapid and accurate diagnostic tests in both veterinary and food analysis laboratories.

\section{ACKNOWLEDGMENTS}

We thank Cenbiot Enzimas (Centro de Biotecnologia, Universidade Federal do Rio Grande do Sul, Porto Alegre, Brazil) for providing the Taq DNA Polymerase, Fundação Osvaldo Cruz for serotyping the Salmonella isolates and C.D. Castagna for help in the statistical analysis. Scholarships were provided for S.M.F. Castagna and C.R. Rodenbusch by the Brazilian agency Conselho Nacional de Pesquisa (CNPq), for Monika Muller by Coordenação de Aperfeiçoamento de Pessoal de Ensino Superior (CAPES) and for M. Macagnan by the Fundação de Amparo a Pesquisa do Estado do Rio Grande do Sul (FAPERGS), these agencies also provided general financial support for this research. 


\section{RESUMO}

\section{Detecção de Salmonella sp. em amostras de origem suína: comparação entre a técnica da Reação em Cadeia da Polimerase e o isolamento bacteriano convencional}

O objetivo desse estudo foi comparar um método de Reação em Cadeia da Polimerase (PCR) combinado com enriquecimento seletivo em caldo Rappaport-Vassiliadis (PCR-RVB) com as técnicas de isolamento bacteriano convencional (SMT) para a detecção do gênero Salmonella em amostras de origem suína. Duzentas e sessenta e oito amostras de campo, compostas por: 42 "pools" de linfonodos mandibulares e tonsilas, 44 amostras de conteúdo intestinal, 38 amostras de massa de embutidos e 144 amostras de ração coletadas em granjas foram submetidas ao protocolo de PCR-RVB e SMT. Salmonella foi detectada em 54 amostras usando o PCR-RVB e em 42 amostras pelo SMT; três amostras positivas no SMT (isolados de, respectivamente, $S$. Derby, $S$. Panama e $S$. Typhimurium) foram negativas no PCRRVB. Quinze amostras positivas no PCR-RVB foram negativas no SMT, uma diferença considerada significativa de acordo com o teste de Mac Nemar ( $p=0,0153)$. A tipificação antigênica dos isolados do SMT revelou a presença dos seguintes sorovares de Salmonella, sendo demonstrado entre parênteses o número de isolados: Typhimurium (12); Bredeney (10); Panama (5); Saint-paul (5); Minnesota (3); Mbandaka (2); Derby (1); Enteritidis (1); Orion (1) e Salmonella sp. (2). Concluiu-se que, apesar da combinação do PCR-RVB com SMT aumentar o número de amostras positivas, a maior sensibilidade e rapidez do PCR-RVB permitem que o mesmo possa ser adotado na detecção de Salmonella sp. em amostras de origem suína.

Palavras-chave: detecção, PCR, suíno, Salmonella

\section{REFERENCES}

1. Abraira, V. El índice Kappa. SEMERGEN. 27, 247-249, 2000.

2. Bennett, A.R.; Greenwood, D.; Tenant, C.; Banks, J.G.; Betts, R.P. Rapid and definitive detection of Salmonella in foods by PCR. Lett. Appl. Microbiol., 26, 437-441, 1998.

3. Bessa, M.C.; Costa, M.; Cardoso, M. Prevalência de Salmonella sp. em suínos abatidos em frigoríficos sob inspeção federal no Rio Grande do Sul. Pesq. Vet. Bras., 24, 80-84, 2004

4. Candrian, U. Polymerase chain reaction in food microbiology. $J$. Microbiol. Methods., 23, 89-103, 1995.
5. Castagna, S.M.F.; Schwarz, P.; Canal, C.W.; Cardoso, M. Prevalência de suínos portadores de Salmonella sp. ao abate e contaminação de embutidos tipo frescal. Acta Scientiae Veterinariae, 32, 141-147, 2004.

6. del Cerro, A.; Soto, S.M.; Landeras, E.; Gonzáles-Hervia, M.A.; Guijarro, J.A.; Mendonza, M.C. PCR-based procedures in detection and DNA-fingerprinting of Salmonella from samples of animal origin. Food Microbiol., 19, 567-575, 2002.

7. Fluit, A.C.; Widjojoatmodjo, M.N.; Box, A.T.A.; Torensma, R.; Verhoef, J. Rapid detection of salmonellae in poultry with the magnetic immuno-polymerase chain reaction. Appl. Environ. Microbiol., 59, 1342-1346, 1993.

8. Fricker, C.R. The isolation of salmonellas and campylobacters. $J$. Appl. Bacteriol., 63, 99-116, 1987.

9. Galán, J.E.; Ginocchio, C.; Costeas, P. Molecular and functional characterization of the Salmonella invasion gene invA: homology of invA to members of a new protein family. J. Bacteriol., 174 4338-4349, 1992.

10. Geimba, M.P.; Tondo, E.C.; Oliveira, F.A.; Canal, C.W.; Brandelli, A. Serological characterization and prevalence of $s p v \mathrm{R}$ genes in Salmonella isolated from foods involved in outbreaks in Brazil. J. Food Protect., 67, 1229-1233, 2004.

11. Gouws, P.A.; Visser, M.; Brözel, V.S. A polymerase chain reaction procedure for the detection of Salmonella spp. within 24 hours. $J$. Food Protec., 61, 1039-1042, 1998.

12. Holt, J.G.; Bergey's Manual of Determinative Bacteriology. 9.ed. Baltimore: Williams \& Wilkims, 1994. 787 p.

13. Hoorfar, J.; Baggesen, D.L.; Porting, P.H. A PCR-based strategy for simple and rapid identification of rough presumptive Salmonella isolates. J. Microbiol. Methods., 35, 7-84, 1999.

14. Malorny, B.; Hoorfar, J.; Bunge, C.; Helmuth, R. Multicenter validation of the analytical accuracy of Salmonella PCR: towards an international standard. Appl. Environm. Microbiol., 69, 290-296, 2003.

15. Oliveira, S.D.; Santos, L.R.; Schuch, D.M.T.; Silva, A.B.; Salle, C.T.P.; Canal, C.W. Detection and identification of salmonellas from poultry by PCR. Vet. Microbiol., 87, 25-35, 2002.

16. Oliveira, S.D.; Rodenbusch, C.R.; Cé, M.C.; Rocha, S.L.S.; Canal, C.W. Evaluation of selective and non-selective enrichment PCR procedures for Salmonella detection. Lett. Appl. Microbiol., 36, 217-221, 2003.

17. Rahn, K.; De Grandis, S.A.; Clarke, R.C.; Galán, J.E.; Ginocchio, C.; Curtiss III, R.; Gyles, C.L. Amplification of an invA gene sequence of Salmonella Typhimurium by polymerase chain reaction as a specific method of detection of Salmonella. Mol. Cell. Probes., 6, 271-279, 1992.

18. Schrank, I.S.; Mores, M.A.Z.; Costa, J.L.A.; Frazzon, A.P.G.; Soncini, R.; Schrank, A.; Vainstein, M.H.; Silva, S.C. Influence of enrichment media and application of a PCR based method to detect Salmonella in poultry industry products and clinical samples. Vet. Microbiol. $82,45-53,2001$.

19. Stone, G.G.; Oberst, R.D.; Hays, M.P.; McVey, S.; Chengappa, M.M. Detection of Salmonella serovars from clinical samples by enrichment broth cultivation-PCR procedure. J. Clin. Microbiol, 32, 1742-1749, 1994.

20. Thursfield, M. Veterinary Epidemiology. London: Butterworths, 1986. 